\title{
ANALISA PERATURAN OTORITAS JASA KEUANGAN (POJK) NOMOR 77/POJK.01/2016 TENTANG LAYANAN PINJAM MEMINJAM UANG BERBASIS TEKNOLOGI INFORMASI (LPMUBTI) TERHADAP PENGGUNAAN FINANCIAL TECHNOLOGY (FINTECH) PADA INDUSTRI JASA PERBANKAN DI WILAYAH III CIREBON
}

\author{
Diana Fitriana, Nur Rahman, Abdul Wahid \\ Universitas Bhayangkara Jakarta Raya,Universitas Muhammadiyah Cirebon \\ e-mail: diana243jonna@gmail.com,nur.rahman@umc.ac.id, abdul.wahid@umc.ac.id
}

\begin{abstract}
Abstrak
Teknologi membuat sistem keuangan konvensional terlihat tidak praktis dan memakan waktu yang cukup lama. Kantor bank atau ATM pun menjadi kurang diminati, dari transaksi jual beli sampai urusan pinjam meminjam danapun bisa diakses dengan internet serta ponsel canggih, dan urusan transaksi keuangan jauh dari kata kaku dan berbelit. Namun, fenomena ini memberikan dampak baik secara langsung maupun tidak langsung kepada industri jasa perbankan sebagai penyedia jasa layanan keuangan resmi, perbankan sudah lebih dulu memberikan pengenalan produk bank, jasa pinjaman bank dan lain sebagainya kepada masyarakat. Otoritas Jasa Keuangan (OJK) telah membuat aturan untuk ditaati oleh penyelenggara bisnis pinjaman dari pengguna ke pengguna, atau biasa disebut dengan Fintech peer to peer lending (P2P lending) yaitu POJK Nomor 77/POJK.01/2016, peraturan ini bertujuan untuk melindungi konsumen terkait keamanan dana dan data, pencegahan pencucian uang dan pendanaan terorisme, stabilitas sistem keuangan, hingga para pengelola perusahaan Fintech.
\end{abstract}

Kata kunci: Financial Technology (Fintech), Otoritas Jasa Keuangan (OJK), Bank.

\begin{abstract}
Technology makes conventional financial systems seem impractical and time consuming. Bank offices or ATMs are also becoming less desirable, from buying and selling transactions to lending and borrowing and funds can be accessed with the internet and smart phones, and financial transactions are far from rigid and complicated. However, this phenomenon has an impact both directly and indirectly on the banking service industry as an official financial service provider, banks have already introduced bank products, bank loan services and so on to the public. The Financial Services Authority (OJK) has made rules to be obeyed by lending business operators from user to user, or commonly known as Fintech peer to peer lending (P2P lending), namely POJK Number 77 / POJK.01 / 2016, this regulation aims to protect consumers related to security of funds and data, prevention of money laundering and terrorism financing, financial system stability, to managers of Fintech companies.
\end{abstract}

Keywords: Financial Technology (Fintech), Financial Services Authority (OJK), Bank. 


\section{A. Pendahuluan}

Wilayah III Cirebon tidak luput menjadi sasaran empuk para Fintech illegal atau abal-abal. Sudah ratusan warga Cirebon yang menjadi korban pinjol (pinjaman online). Salah satu warga Cirebon yang menjadi korban mengaku terpikat dengan iklan aplikasi rentenir online karena menawarkan kemudahan mendapatkan uang, hanya dengan syarat menginput data KTP. Setelah mendownload aplikasi itu, mengisi data data pribadi yang diminta oleh aplikasi, namun ditengah jalan mengurungkan niatnya dan membatalkan rencana meminjam uang di pinjaman online, bahkan sudah menghapus aplikasi tersebut dari smartphone nya. Namun, sebulan kemudian mendapati SMS berisi tagihan utang sebesar Rp. 1.600.000,(satu juta enam ratus ribu rupiah), sekali dua kali diabaikannya SMS tersebut mengingat dia tidak merasa meminjam uang, hingga pada akhirya Mira mendapati SMS bernada ancaman serius agar Mira mengembalikan pinjaman uangnya, sang debt collector. ${ }^{1}$

Hal ini sangat menimbulkan keresahan bagi warga masyarakat Cirebon, dan masih banyak lagi korbankorban lainnya yang terjerat rentenir online ini. Kedepannya diharapkan adanya payung hukum bagi Fintech/rentenir online atau pinjaman online ini, maka Fintech yang operasionalnya tidak memiliki izin dan terdaftar di OJK maka langsung masuk tindak pidana. Fintech $^{2}$ atau pinjol

Online,

${ }^{1}$ Ratusan Warga Cirebon Terjebak Rentenir

https://www.radarcirebon.com/2019/07/25/ratusan-

warga-cirebon-terjebak-rentenir-online/ diakses pada tanggal 18 Agustus 2019.

2 Fintech merupakan singkatan dari financial technology. Berdasarkan National Digital Research Center (NDRC) mendefinisikan sebagai istilah yang dapat digunakan untuk menyebut inovasi dalam bidang jasa keuangan atau finansial. Inovasi yang dimaksud adalah inovasi finansial yang diberikan sentuhan teknologi modern. Sederhananya, fintech adalah jenis perusahaan di bidang jasa keuangan yang digabungkan memang inovasi keuangan yang mengikuti perkembangan teknologi. Namun kemunculan Fintech ilegal ini akan menjadi masalah untuk masyarakat kedepannya. Adanya Undang-Undang ini juga diharapkan dapat menutup celah kehadiran Fintech-Fintech bodong atau tidak berizin. Tongam juga menyampaikan, meskipun satgas waspada investasi sudah banyak menutup kegiatan Fintech Peer-To-Peer Lending tanpa izin, tetap saja banyak Fintech yang terus bermunculan secara ilegal.

Menurut Otoritas Jasa Keuangan (OJK) Cirebon, Muhammad Luthfi, perkembangan Fintech abal-abal tidak terlepas dari kemudahan teknologi yang semakin terbuka. Luthfi melanjutkan, selain harus berkejaran dengan Fintech illegal yang dengan cepat sekali mengganti platform dan ganti nama yang bertujuan untuk mengelabui masyarakat, pihaknya juga mesti mengedukasi masyarakat agar tidak menjadi korban berikutnya. $^{3}$

Kehadiranya globalisasi di era millennium ini telah membawa dampak yang besar di seluruh sektor kehidupan manusia termasuk salah satunya adalah teknologi dan internet. Teknologi dan internet memiliki peran yang begitu besar dalam menunjang segala aktivitas

dengan teknologi. Bisa juga diartikan sebagai segmen di dunia startup yang membantu untuk memaksimalkan penggunaan teknologi untuk mempertajam, mengubah, dan mempercepat berbagai aspek pelayanan keuangan. Sehingga, mulai dari metode pembayaran, transfer dana, pinjaman, pengumpulan dana, sampai dengan pengelolaan aset bisa dilakukan secara cepat dan singkat berkat penggunaan teknologi modern tersebut. Maka tidak heran jika kemudian financial technology menjadi kebutuhan yang bisa mengubah gaya hidup seseorang, khususnya mereka yang familiar atau bergelut di bidang keuangan dan teknologi. Lihat Rani Maulida, Fintech: Pengertian, Jenis, Hingga Regulasinya di Indonesia, https://www.online-pajak.com/tentang-pajakpribadi/fintech diakses pada tanggal 27 November 2019.

3 Sylke Febrina Laucereno, Basmi Rentenir Online, Undang-undang Fintech Harus Dibuat!, https://finance.detik.com/fintech/d-4649564/basmirentenir-online-undang-undang-fintech-harus-dibuat, Jumat, 02 Agustus 2019, diakses pada tanggal 18 Agustus 2019 pukul 20.06 WIB. 
kehidupan manusia. Pemanfaatan teknologi digital di Indonesia yang sangat besar tentu saja memberikan dampak bagi beberapa sektor, salah satunya adalah sektor bisnis atau industri bisnis yang kemudian melahirkan perdagangan online atau e-commerce. Namun, dampak dari semakin pesatnya perkembangan teknologi dan internet tidak hanya merambah industri perdagangan, tetapi juga pada industri keuangan Indonesia. Hal tersebut ditandai dengan hadirnya financial technology (Fintech). ${ }^{4}$

Layanan keuangan digital atau financial technology (Fintech) dilaksanakan dengan berlandaskan payung hukum. Hal ini menyusul setelah dikeluarkannya Peraturan Otoritas Jasa Keuangan (POJK) Nomor 77/POJK.01/2016, tentang Layanan Pinjam Meminjam Uang Berbasis Teknologi Informasi (LPMUBTI). Di dalam aturan tersebut, OJK mengatur berbagai hal yang harus ditaati oleh penyelenggara bisnis pinjaman dari pengguna ke pengguna, atau yang biasa disebut dengan peer to peer lending ( $\mathrm{P} 2 \mathrm{P}$ lending). Sehingga pada akhirnya ini akan melindungi kepentingan konsumen terkait keamanan dana dan data, serta kepentingan nasional terkait pencegahan pencucian uang dan pendanaan terorisme, serta stabilitas sistem keuangan. ${ }^{5}$

Maraknya kasus pinjaman online pasca terbitnya POJK sudah cukup membuktikan bahwa regulasi tersebut belum memberikan perlindungan terhadap konsumen yang menggunakan layanan pinjaman online. Nyatanya hari ini kita bisa lihat permasalahan ini muncul dan marak, padahal POJK terbit 2016 tapi kasus ini marak setelah tahun

4 Ernama, Budiharto, Hendro S., Pengawasan Otoritas Jasa Keuangan Terhadap Financial Technology (Peraturan Otoritas Jasa Keuangan Nomor 77/POJK.01/2016), Diponegoro Law Journal, Vol. 6, No.3, (2017), . 1-2.

${ }^{5}$ detikFinance.com, Selasa 10 Januari 2017 17:31 WIB, OJK Keluarkan Aturan Fintech, dalam http://www.detikfinance.com, diakses Kamis, 8 Maret 2019 pukul 15:10 WIB.
2016. Itu karena aturannya tidak cukup melindungi. Pengaturan dan pengawasan menjadi sangat penting bagi keberlangsungan Fintech yang ada di Indonesia. Hal ini berkaitan dengan legalitas dari bisnis yang dijalankan karena pada pelaksanaannya pengembangan Fintech memiliki potensi risiko yakni berkaitan dengan perlindungan konsumen, stabilitas sistem keuangan, sistem pembayaran dan stabilitas ekonom. Tujuan pengaturan dan pengawasan oleh OJK adalah untuk meminimalisir risiko tersebut dan menunjang pertumbuhan ekonomi yang berkelanjutan dan stabil.

Layanan financial technology (Fintech) pinjaman online, termasuk layanan pinjol ilegal alias abal-abal. Meskipun satuan tugas waspada investasi sudah memblokir ribuanaplikasi abal-abal tersebut, namun masih banyak yang 'berkeliaran' mencari mangsa. ${ }^{6}$ Ketua Satgas Waspada Investasi Tongam L Tobing mengatakan, saat ini undangundang (UU) terkait Fintech atau pinjaman secara online sangat dibutuhkan. Itu diperlukansebagai landasan hukum menghentikan Fintech abal-abal yang makin meresahkan masyarakat.

Dari latar belakang diatas, penulis merumuskan masalah sebagai berikut :

1. Bagaimana aturan dalam Peraturan Otoritas Jasa Keuangan (POJK) Nomor 77/Pojk.01/2016 Tentang Layanan Pinjam Meminjam Uang Berbasis Teknologi Informasi (LPMUBTI) dapat digunakan sebagai dasar melawan permainan Fintech abal-abal?

2. Bagaimana peranan aturan Peraturan Otoritas Jasa Keuangan (POJK) Nomor 77/Pojk.01/2016 Tentang Layanan Pinjam Meminjam Uang Berbasis Teknologi Informasi

6 Sylke Febrina Laucereno, Op.,cit. https://finance.detik.com/fintech/d-4649564/basmirentenir-online-undang-undang-fintech-harus-dibuat. ${ }^{7}$ Ibid. 
(LPMUBTI) dalam melindungi masyarakat khususnya warga wilayah III Cirebon dan aturan sanksi yang sesuai bagi Fintech abal-abal

\section{B. Metode Penelitian}

Metode yang digunakan dalam penelitian ini menggunakan pendekatan metode yuridis normatif, yaitu: Pendekatan yang bertitik tolak dari ketentuan peraturan perundang-undangan dan diteliti di lapangan untuk memperoleh faktor pendukung dan hambatannya. Pendekatan yuridis normatif ini merupakan pendekatan dengan berdasarkan norma-norma atau peraturan perundang-undangan yang mengikat serta mempunyai konsekuensi hukum yang jelas. Melalui pendekatan yuridis normatif ini diharapkan dapat mengetahui tentang suatu peraturan perundang-undangan yang berlaku untuk dapat diterapkan dalam mengkaji dan membahas permasalahan-permasalahan dalam penelitian ini. ${ }^{8}$

Metode pengumpulan data dalam penelitian ini adalah dengan menggunakan dua cara yaitu studi kepustakaan (library research) untuk mengumpulkan data sekunder untuk mengumpulkan data primer. Data primer merupakan data yang berasal dari masyarakat dan atau orang yang terlibat secara langsung terhadap masalah yang diteliti. ${ }^{9}$ Sehingga penelitian ini dilakukan dengan mengkaji data primer yang ada di lapangan yang berada di Otoritas Jasa Keuangan Surakarta terkait pelaksanaan pemberian kredit berbasis teknologi informasi oleh Fintech kepada pelaku usaha kecil dan menengah berdasarkan Peraturan Otoritas Jasa Keuangan (POJK) Nomor 77/POJK.01/2016. Jenis penelitian yang

\footnotetext{
${ }^{8}$ Soerjono Soekanto dan Sri Mamudji, Penelitian Hukum Normatif Suatu Tinjauan Singkat, (Jakarta; Rajawali Press, 2010), . 17.

9 H. Salim HS dan Erlies Septiana Nurbani, Penerapan Teori Hukum Pada Penelitian Tesis dan Disertasi, (Jakarta: PT RajaGrafindo Persada, 2013), . 20.
}

digunakan penulis dalam penelitian ini adalah penelitian deskriptif. ${ }^{10}$

Penulis mengambil lokasi di Otoritas Jasa Keuangan Cirebon. Data yang disajikan dari sumber-sumber data yang meliputi data primer dan data sekunder. Data primer yaitu data yang diperoleh berupa fakta atau keterangan hasil penelitian secara langsung di lokasi penelitian dan hasil wawancara dengan pihak Otoritas Jasa Keuangan Cirebon. Sedangkan data kepustakaan adalah data yang diperlukan dalam penelitian ini adalah data sekunder yang berupa bahanbahan hukum yang terdiri dari bahan hukum primer, yaitu bahan hukum yang bersifat mengikat dan bahan hukum sekunder. ${ }^{11}$

\section{Dasar Hukum Melawan Permainan Fintech Ilegal}

Otoritas Jasa Keuangan (OJK) menyebutkan sejak periode 2017 hingga saat ini telah ditemukan sebanyak 2.500 perusahaan teknologi finansial ilegal atau Fintech yang tak berizin beroperasi dan memberikan pinjaman kepada masyarakat. Rata-rata, kata dia, masyarakat yang menjadi korban Fintech ilegal adalah masyarakat yang membutuhkan dana untuk konsumtif. Hal ini akan memberatkan masyarakat sehingga terjebak pada pinjaman ilegal. Catatan OJK, sampai saat ini terdapat 151 Fintech resmi, dan telah menyalurkan pinjaman kepada hampir 24 juta orang dengan outstanding kredit sebesar hampir Rp15 triliun. ${ }^{12}$

Istilah Fintech yang merupakan akronim darifinancial technology sudah tak asing lagi di dunia bisnis Indonesia

10 Soerjono Soekanto, Pengantar Penelitian Hukum, (Jakarta: Penerbit Universitas Indonesia (UIPress), 2005), . 10.

11 Khudzaifah Dimyati dan Kelik Wardiono, Metode Penelitian Hukum (Buku Pegangan Kuliah), (Surakarta: Universitas Muhammadiyah Surakarta, 2015), . 8 .

12 Sejak 2017, OJK Sudah Temukan 2.500 Fintech Tak Berizin, 29 Mei 2020. https://www.radarcirebon.com/2020/05/29/sejak-2017ojk-sudah-temukan-2-500-fintech-tak-berizin/ diakses pada tanggal 01 Juni 2020. 
beberapa tahun belakangan. Salah satu definisi Fintech dari sebuah pusat penelitian digital di Irlandia adalah "innovation in financial services" atau inovasi dalam layanan keuangan. Jika sulit memahaminya, ingat-ingat saja pembayaran dengan uang elektronik anda pagi ini, investasi via online atau pembiayaan dengan patungan online yang dilakukan bersama di situs tertentu. Itulah beberapa contoh penggunaan Fintech dalam transaksi keuangan. Pesatnya perkembangan industri Fintech ini pun semakin dirasa penting bagi para konsultan hukum di pasar modal dan keuangan. Sebenarnya apapun teknologi yang berkaitan dengan layanan jasa keuangan itu masuk dalam definisi financial technology, tapi teknologinya kali ini berevolusi. ${ }^{13}$

Fintech yang dimaksud pada masa kini telah mengembangkan berbagai produk serupa perbankan dan jasa keuangan lainnya yang lebih efisien. Sehingga akhirnya menghasilkan industri tersendiri yang produknya beririsan dengan komoditas berbagai lembaga keuangan konvensional. Meskipun adapula produk dari industri Fintech yang menggandeng produk dari lembaga keuangan konvensional seperti perusahaan perbankan, investasi, dan perasuransian. Sebagai industri baru yang muncul akibat kemajuan teknologi membuat aspek hukum Fintech masih terus berkembang dan tidak dapat ditampung dengan berbagai regulasi yang ada saat ini. Abi mengemukakan bahwa fenomena ini terjadi pada berbagai sistem hukum di dunia. Apalagi kehadiran Fintech yang bersandar pada internet of things membuat industri ini mampu beroperasi melintas batas berbagai yurisdiksi. Industri Fintech ini terdiri dari berbagai start up yang masih

13 Abi Tisnadisastra dalam seminar Himpunan Konsultan Hukum Pasar Modal (HKHPM), Rabu, 28 Februari 2018, Aspek Hukum Fintech di Indonesia yang Wajib Diketahui

Lawyer, https://www.hukumonline.com/berita/baca/lt5a97b39446 0ec/aspek-hukum-fintech-di-indonesia-yang-wajibdiketahui-lawyer/ diakses pada tanggal 29 Mei 2020. dalam tahap perkembangan dengan bergantung suntikan dana investor. Tentunya, para investor menginginkan jaminan hukum bahwa industri ini legal berdasarkan berbagai regulasi tekait. Dan untuk mendapatkan kepercayaan pengguna Fintech dalam hal perlindungan konsumen, berbagai produk Fintech juga membutuhkan pengakuan dari regulator. ${ }^{14}$

Dalam Peraturan Bank Indonesia No.19/12/PBI/2017 tentang Penyelenggaraan Teknologi Finansial (PBI Tekfin) telah ditegaskan definisi yang digunakan oleh BI mengenai Fintech hingga kategori dan kriterianya.

Definisi Teknologi Finansial/Fintech Pasal 1:

Teknologi

Finansial adalah penggunaan teknologi dalam sistem keuangan yang menghasilkan produk, layanan, teknologi, dan/atau model bisnis baru serta dapat berdampak pada stabilitas moneter, stabilitas sistem keuangan, dan/atau efisiensi, kelancaran, keamanan, dan keandalan sistem pembayaran.

Kategori Penyelenggaraan Teknologi Finansial/Fintech Pasal 3 ayat 1:

(1) Sistem pembayaran;

Pendukung pasar; (3) Manajemen investasi dan manajemen risiko; (4) Pinjaman, pembiayaan, dan penyediaan modal; dan (5) Jasa finansial lainnya.

Kriteria Teknologi Finansial/Fintech Pasal 3 ayat 2:

(1) Bersifat inovatif; (2) Dapat berdampak pada produk, layanan, teknologi, dan/atau model bisnis finansial yang telah eksis; (3) Dapat memberikan manfaat bagi masyarakat; (4) Dapat digunakan secara luas; dan (5) Kriteria lain yang ditetapkan oleh Bank Indonesia.

14 Abi Tisnadisastra dalam seminar Himpunan Konsultan Hukum Pasar Modal (HKHPM), Rabu, 28 Februari 2018, Aspek Hukum Fintech di Indonesia yang Wajib Diketahui Lawyer, https://www.hukumonline.com/berita/baca/lt5a97b39446 0ec/aspek-hukum-fintech-di-indonesia-yang-wajibdiketahui-lawyer/ diakses pada tanggal 29 Mei 2020. 
Sementara itu, OJK baru menerbitkan satu pengaturan yang berkaitan dengan salah satu produk Fintech melalui Peraturan Otoritas Jasa Keuangan No.77/POJK.01/2016 tentang Layanan Pinjam Meminjam Uang Berbasis Teknologi Informasi. Sejauh ini sebenarnya sudah ada enam kegiatan Fintech yang diatur dalam sistem pembayaran dan sistem jasa keuangan di Indonesia sebagai berikut: ${ }^{15}$

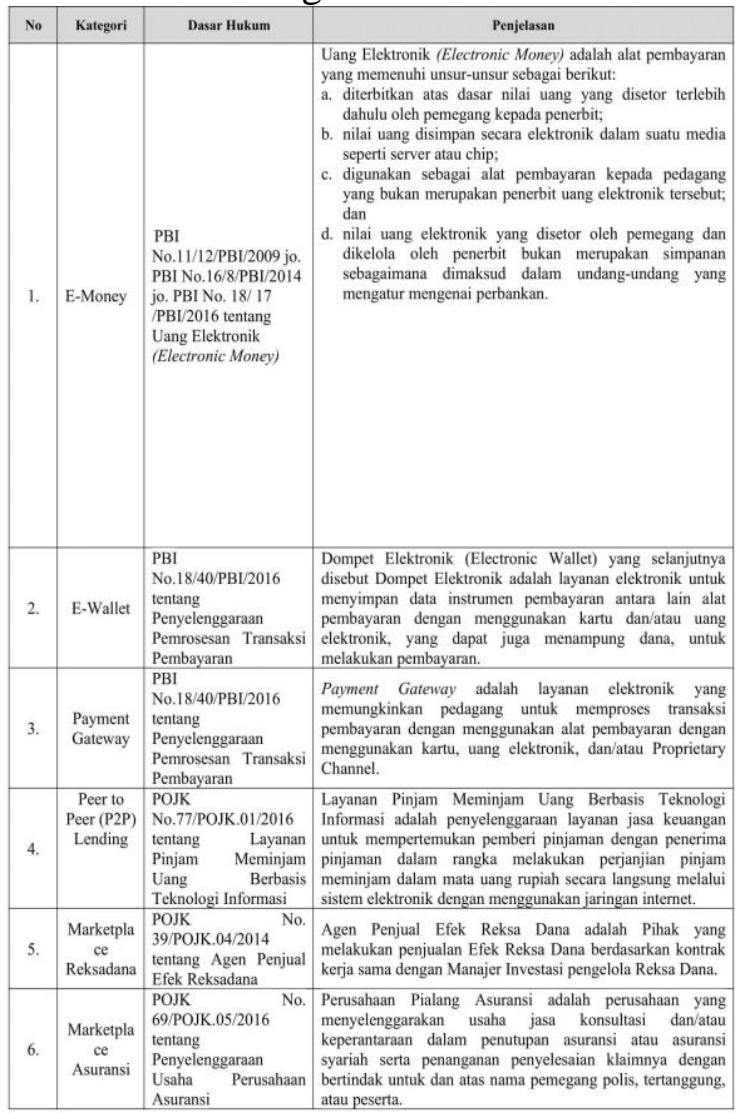

Otoritas Jasa Keuangan (OJK) mengeluarkan Peraturan OJK No. 13/POJK.02/2018 tentang Inovasi Keuangan Digital di Sektor Jasa Keuangan. Aturan ini merupakan ketentuan yang memayungi pengawasan dan pengaturan industri financial

15 Abi Tisnadisastra dalam seminar Himpunan Konsultan Hukum Pasar Modal (HKHPM), Rabu, 28 Februari 2018, Aspek Hukum Fintech di Indonesia yang Wajib Diketahui Lawyer, https://www.hukumonline.com/berita/baca/lt5a97b39446 0ec/aspek-hukum-fintech-di-indonesia-yang-wajibdiketahui-lawyer/ diakses pada tanggal 29 Mei 2020. technology (Fintech). Peraturan ini dikeluarkan OJK mengingat cepatnya kemajuan teknologi di industri keuangan digital yang tidak dapat diabaikan dan perlu dikelola agar dapat memberikan manfaat sebesar-besarnya untuk kepentingan masyarakat, Inovasi keuangan digital perlu diarahkan agar menghasilkan inovasi keuangan digital yang bertanggung jawab, aman, mengedepankan perlindungan konsumen dan memiliki risiko yang terkelola dengan baik. Peraturan ini juga dikeluarkan sebagai upaya mendukung pelayanan jasa keuangan yang inovatif, cepat, murah, mudah, dan luas serta untuk meningkatkan inklusi keuangan, investasi, pembiayaan serta layanan jasa keuangan lainnya. Pokok-pokok pengaturan Inovasi Keuangan Digital (IKD) antara lain: ${ }^{16}$

\section{a. Mekanisme Pencatatan dan Pendaftaran Fintech}

Setiap penyelenggara IKD baik perusahaan Startup maupun Lembaga Jasa Keuangan (LJK) melalui 3 (tiga) tahap proses sebelum mengajukan permohonan perizinan:

1) Pencatatan kepada OJK untuk perusahaan Startup/non-LJK. Permohonan pencatatan secara otomatis termasuk permohonan pengujian Regulatory Sandbox. Sedangkan untuk LJK, permohonan Sandbox diajukan kepada pengawas masing-masing bidang (Perbankan, Pasar Modal, IKNB).

2) Proses Regulatory Sandbox berjangka waktu paling lama satu tahun dan dapat diperpanjang selama 6 bulan bila diperlukan.

3) Pendaftaran/perizinan kepada OJK.

\section{b. Mekanisme Pemantauan dan Pengawasan Fintech}

16 Herdaru Purnomo, Indonesia Kini Punya Payung Hukum Aturan Fintech, 01 September 2018, https://www.cnbcindonesia.com/tech/2018090114474037-31329/indonesia-kini-punya-payung-hukum-aturanfintech diakses pada tanggal 20 Juni 2020. 
OJK menetapkan Penyelenggara IKD yang wajib mengikuti proses Regulatory Sandbox. Hasil uji coba Regulatory Sandbox ditetapkan dengan status:

1) Direkomendasikan.

2) Perbaikan.

3) Tidak direkomendasikan.

Penyelenggara IKD yang sudah menjalani Regulatory Sandbox dan berstatus direkomendasikan dapat mengajukan permohonan pendaftaran kepada OJK. Untuk pelaksanaan pemantauan dan pengawasan, penyelenggara IKD diwajibkan untuk melakukan pengawasan secara mandiri dengan menyusun laporan self assessment yang sedikitnya memuat aspek tata kelola dan mitigasi risiko. Penyelenggara IKD dilarang mencantumkan nama dan/atau logo OJK namun dapat mencantumkan nomor tanda tercatat/terdaftar. Dalam jangka menengah, OJK dapat menunjuk pihak lain (Asosiasi Penyelenggara IKD yang diakui oleh OJK) yang bertugas dalam pengawasan IKD.

c. Pembentukan Ekosistem Fintech

Untuk memelihara ekosistem keuangan, Lembaga Jasa Keuangan yang telah memperoleh izin atau terdaftar di OJK dilarang bekerja sama dengan Penyelenggara IKD yang belum tercatat di OJK atau terdaftar di otoritas lain yang berwenang guna memelihara ekosistem keuangan.

d. Membangun Budaya Inovasi

OJK menginisiasi pembentukan Pusat Inovasi Keuangan Digital (Fintech Center) dan ekosistem IKD yang bertujuan sebagai sarana komunikasi, koordinasi, dan kolaborasi antara otoritas terkait dan pelaku IKD serta wadah Inovasi dan Pengembangan IKD.

\section{e. Inklusi dan Literasi}

\section{Penyelenggara}

melaksanakan kegiatan untuk meningkatkan literasi dan inklusi keuangan kepada masyarakat.

\section{f. Bisnis dan Perlindungan Data}

Penyelenggara IKD wajib menyediakan pusat pelayanan konsumen berbasis teknologi sebagai bentuk penerapan edukasi dan perlindungan konsumen beserta usahanya.

\section{g. Manajemen Risiko yang Efektif}

Penyelenggara IKD wajib menerapkan prinsip pemantauan secara mandiri, menginventarisasi risiko utama, menyusun laporan risk self assessment secara bulanan, dan memiliki perangkat yang dapat meningkatkan efisiensi dan kepatuhan atas proses pemantauan yang dilakukan oleh OJK.

\section{h. Kolaborasi}

Dengan dibentuknya Fintech Center maka dapat membantu berjalannya proses Regulatory Sandbox sebagai langkah inkubasi model bisnis yang inklusif dan memenuhi prinsip kehati-hatian serta meningkatkan sinergi antar industri, pemerintah, akademisi dan innovation hub lain.

\section{i. Perlindungan Konsumen}

Penyelenggara wajib menerapkan prinsip dasar perlindungan konsumen yaitu (a) transparansi, (b) perlakuan yang adil, (c) keandalan, kerahasiaan dan keamanan data/informasi konsumen, dan (e) penanganan pengaduan serta penyelesaian sengketa konsumen secara sederhana, cepat, dan biaya terjangkau.

\section{j. Transparansi}

Penyelenggara IKD wajib menerapkan prinsip pengawasan berbasis disiplin pasar, risiko dan teknologi terhadap inovasinya antara lain harus memperhatikan transparansi produk dan layanan, pasar yang kompetitif dan inklusif, kesesuaian dengan kebutuhan konsumen, penanganan mekanisme keluhan yang segera, dan aspek keamanan dan kerahasiaan data konsumen dan transaksi. 


\section{k. Anti-Pencucian Uang dan Pendanaan Terorisme}

Penyelenggara IKD juga wajib menerapkan program anti pencucian uang dan pencegahan pendanaan terorisme di sektor jasa keuangan terhadap konsumen sesuai ketentuan Peraturan OJK di bidang AML-CFT (Anti Money Laundering and CounterFinancing of Terrorism). Sebelumnya OJK telah mengeluarkan peraturan mengenai Fintech peer to peer lending melalui POJK 77/POJK.01/2016 Tentang Layanan Pinjam Meminjam Uang Berbasis Teknologi Informasi.

Dengan adanya Peraturan Otoritas Jasa Keuangan (POJK) Nomor 77/Pojk.01/2016 Tentang Layanan Pinjam Meminjam Uang Berbasis Teknologi Informasi (LPMUBTI) kemudian diperkuat lagi dengan Peraturan OJK No. 13/POJK.02/2018 tentang Inovasi Keuangan Digital di Sektor Jasa Keuangan. Jadi, praktik Fintech illegal atau abal-abal yang merugikan masyarakat khususnya di Wilayah III Cirebon inilah yang menjadi dasar hukum sebagai dasar melawan permainan Fintech abal-abal.

D. Perlindungan Hukum Warga Wilayah III Cirebon terhadap Fintech Ilegal

1. Peraturan Otoritas Jasa Keuangan (POJK)

Sebagai langkah awal, OJK telah mengeluarkan POJK No. 77/ POJK.01/2016 tentang Layanan Pinjam Meminjam Uang Berbasis Teknologi Informasi (POJK P2P Lending) yang kemudian memiliki peraturan turunan berupa Surat Edaran OJK (SEOJK) nomor 18/ SEOJK.02/2017. POJK ini mengatur mengenai salah satu jenis Fintech yang berkembang di Indonesia saat ini yaitu Peer-to-Peer Lending (P2P Lending). Hal tersebut dikarenakan OJK melihat urgensi hadirnya ketentuan yang mengatur Fintech pinjam-meminjam, memperhatikan masih kuatnya budaya pinjam meminjam (utang) di masyarakat
Indonesia. Selain itu, perusahaan Fintech dengan skema Peer to Peer Lending merupakan lingkup kewenangan OJK dikarenakan perusahaan tersebut memberikan pelayanan jasa keuangan.

Setelah berlakunya POJK Nomor 77/POJK.01/2016 tentang Layanan Pinjam meminjam Uang Berbasis Teknologi Informasi, OJK telah mengeluarkan ketentuan tentang pelaksanaan tata kelola dan manajemen risiko Teknologi Informasi pada layanan pinjam meminjam uang berbasis teknologi dalam SEOJK Nomor : 18/ SEOJK.02/2017 yang mulai berlaku pada tanggal ditetapkan yaitu 18 April 2017. Ruang lingkup yang diatur meliputi:

a) Penempatan pusat data dan pemulihan bencana serta rencana pemulihan bencana;

b) Tata Kelola Sistem Elektronik dan teknologi Informasi yang meliputi Rencana Strategis Sistem Elektronik, Sumber Daya manusia, dan Pengelolaan Perubahan Teknologi Informasi;

c) Alih Kelola Teknologi;

d) Pengelolaan Data dan Informasi;

e) Pengelolaan Risiko Teknologi Informasi;

f) Pengamanan Sistem Elektronik;

g) Penanganan Insiden dan Ketahanan Terhadap Gangguan;

h) Penggunaan Tanda Tangan Elektronik;

i) Ketersediaan Layanan dan Kegagalan Transaksi;

j) Keterbukaan Informasi Produk dan Layanan.

2. Aspek Perlindungan Fintech di Wilayah Cirebon

$\begin{array}{lr}\text { Kehadiran hukum dalam } \\ \text { masyarakat adalah } & \text { untuk } \\ \text { mengintergrasikan } & \text { dan } \\ \text { mengkoordinasikan } & \text { sebagai } \\ \text { kepentingan dalam masyarakat. } & \text { malam suatu lalu lintas kepentingan, }\end{array}$


perlindungan terhadap kepentingan tertentu hanya dapat dilakukan dengan cara membatasi berbagai kepentingan manusia yang perlu diatur dan dilindungi perlindungan hukum harus melihat tahapan yakni perlindungan hukum lahir dari suatu ketentuan hukum dan segala peraturan hukum yang diberikan oleh masyarakat yang pada dasarnya merupakan kesepakatan masyarakat tersebut untuk mengatur hubungan perilaku antara anggotaanggota masyarakat dan antara perseorangan dengan pemerintah yang dianggap mewakili kepentingan masyarakat. ${ }^{17}$

Dalam fungsinya sebagai perlindungan kepentingan masyarakat, hukum mempunyai tujuan. Tujuan hukum adalah menciptakan tatanan masyarakat yang tertib, menciptakan ketertiban dan keseimbangan. ${ }^{18}$

\section{a. Kelengkapan Informasi dan Transparasi Produk/ Layanan} Fintech wajib

menyediakan informasi secara lengkap, up to date, dan transparan terkait produk atau layanan yang ditawarkan kepada konsumen dan masyarakat. Penyelenggara harus memastikan bahwa informasi yang diberikan bersifat transparan sehingga hal tersebut dapat memberikan kesempatan bagi konsumen untuk memahami dan memilih produk dengan baik serta menghindarkan diri dari risiko yang mereka ingin hindari, seperti misleading advertisement dan penipuan. Aspek kelengkapan informasi dan

17 Sajipto Raharjo, Ilmu Hukum, (Bandung: PT Citra Aditya Bakti, 2014), cet. Ke-8, . 53.

18 Sudikno Mertokusumo, Mengenal Hukum Suatu Pengantar, (Yogyakarta: Universitas Atma Jaya Yogyakarta, 2010), . 93. transparansi pada Fintech di Indonesia harus meliputi biayabiaya dan kewajiban yang akan dikenakan kepada konsumen, transparansi syarat dan ketentuan penggunaan produk/layanan, pemberitahuan kepada konsumen apabila terdapat perubahan biaya, syarat dan ketentuan, kejelasan informasi dari periklanan produk yang dipasarkan seperti pengunaan bahasa yang sederhana dan mudah dipahami dalam media periklanan yang digunakan, seperti website perusahaan, brosur, iklan media masa, online, dan sebagainya.

Penyedia layanan Fintech harus menginformasikan syarat dan ketentuan produk/layanan dalam perjanjian sejelasjelasnya dengan bahasa yang mudah dimengerti, mengingat tingkat literasi keuangan masyarakat Indonesia secara umum relatif masih rendah. Perjanjian juga dilarang menyatakan adanya pengalihan tanggung jawab atau kewajiban dari pelaku Fintech kepada konsumen (klausula eksonerasi). Penyedia layanan Fintech juga harus menghindarkan penggunaan iklan yang berpotensi menciptakan pemahaman yang keliru bagi konsumen dan masyarakat. Bagi masyarakat dan konsumen wajib disediakan kanal informasi yang mudah diakses untuk meminta informasi sejelas-jelasnya dari penyedia layanan Fintech sehingga pemahaman konsumen terhadap produk lengkap dan tercipta awareness (kesadaran) konsumen terhadap biaya dan risiko yang timbul dari penggunaan produk 
(menghindari informasi
asimetris).

b. Penanganan Pengaduan dan Penyelesaian Sengketa Konsumen

Penyedia layanan Fintech di Wilayah III Cirebon harus memiliki perangkat sebagai berikut:

1) Menyediakan jalur atau kanal kontak penerimaan pengaduan yang mudah diakses oleh konsumen, seperti telepon, e-mail, instant messaging, dan surat;

2) Memiliki unit atau fungsi serta prosedur standar penanganan pengaduan konsumen. Prosedur tersebut harus memperhatikan pengaturan perlindungan konsumen yang ada pada POJK terkait dan diinformasikan kepada konsumen;

3) Menyediakan dan menginformasikan kepada konsumen jika terdapat mekanisme alternatif penyelesaian sengketa (alternative dispute resolution) yang dapat digunakan apabila penyelesaian pengaduan dan sengketa secara internal tidak menghasilkan kesepakatan.

c. Pencegahan Penipuan dan Keandalan Sistem Layanan

Pencegahan penipuan atau fraud melalui Fintech merupakan hal penting yang harus diperhatikan regulator seiring dengan makin berkembangnya keragaman tawaran produk/layanan Fintech. Upaya penipuan di Fintech dapat berbentuk seperti penyalahgunaan situs layanan (phising), peretasan terhadap sistem keamanan, dan pemasaran produk/layanan yang menipu. Dengan banyaknya layanan Fintech yang menggunakan media seperti situs jejaring dan aplikasi dalam melakukan promosi dan pemasaran produk/layanannya, maka potensi kerentanan terjadinya penipuan juga meningkat. Para pelaku Fintech wajib memastikan sistemnya andal. Pelaku wajib memiliki sistem keamanan dan aplikasi yang aman dan tersertifikasi agar terhindar dari upaya peretasan oleh pihak yang tidak bertanggung jawab. Pelaku layanan wajib melakukan pemeriksaan dan penyempurnaan sistem secara berkesinambungan karena baik teknologi maupun bentuk ancamannya juga terus berkembang. Peran dari regulator adalah memastikan bahwa sistem keamanan dan aplikasi layanan Fintech selalu dilakukan upaya perbaikan yang diperlukan dan tersertifikasi keandalannya.

d. Perlindungan Terhadap Data Pribadi (Cybersecurity)

Aspek perlindungan terhadap data pribadi menjadi salah satu hal penting yang harus diperhatikan penyedia layanan dan regulator. Sehingga untuk itu, terkait dengan upaya perlindungan terhadap data pribadi dapat dilakukan dengan fokus terhadap hal-hal sebagai berikut:

1) Pelaku layanan Fintech wajib melakukan enkripsi data terhadap data yang berkaitan dengan konsumen; 
2) Pelaku layanan Fintech wajib menjaga keamanan data konsumen;

3) Pelaku layanan Fintech wajib melakukan manajemen akses data;

4) Konsumen mempunyai hak untuk meminta penjelasan dari pelaku terkait penggunaan informasi dan data yang telah diberikannya.

\section{Upaya Peningkatan Perlindungan} Konsumen Fintech di Wilayah Cirebon

Dalam kegiatan pasar, pelaku usaha dan konsumen (pemakai barang atau jasa) sama-sama mempunyai kebutuhan dan kepentingan. Kepentingan pelaku usaha adalah memperoleh laba dari transaksi dengan konsumen, sedangkan kepentingan konsumen adalah memperoleh kepuasan dari segi harga dan mutu barang yang diberikan pelaku usaha. ${ }^{19}$

Sebagaimana amanah yang tertuang dalam Peraturan Otoritas Jasa Keuangan Nomor 1/POJK.07/2013 tentang Perlindungan Konsumen Sektor Jasa Keuangan, Otoritas Jasa Keuangan Cirebon harus mampu melindungi konsumen dan masyarakat di sektor jasa keuangan. Peran aktif dari para otoritas pengaturan dan pengawssan terkait sangatlah diperlukan untuk menyusun pengaturan dan melakukan pengawasan produk dan layanan Fintech dengan tetap memerhatikan aspek perlindungan konsumen.

Bisnis yang dijalankan dalam kegiatan fintech merupakan kegiatan bisnis yang penuh resiko (full risk

19 Erina Pane, Perlindungan Konsumen dalam Persperktif Undang-Undangan Perlindungan Konsumen dan Hukum Islam, Prananta Hukum Vol. 2 No. 1 (Januari 2007) . 60. business) karena aktivasinya sebagian besar berkaitan dengan uang. Oleh karena itu, harus didukung dengan peraturan yang kuat. Hal tersebut sebagai upaya mewujudkan penyelenggaraan fintech yang sehat. ${ }^{20}$

Bentuk perlindungan hukum yang diberikan oleh suatu negara memiliki dua sifat, yaitu bersifat pencegahan (prohibited) dan bersifat hukuman (Sanction). Bentuk perlindungan hukum yang paling nyata adalah adanya institusi-institusi penegak hukum seperti pengadilan, kejaksaan, kepolisian, dan lembagalembaga penyelesaian sengketan diluar pengadilan (non-litigasi) lainnya. $^{21}$

a. Perlidungan Hukum Secara Preventif

Perlindungan Hukum

Secara Preventif Perlindungan hukum bagi pengguna layanan Fintech berbasis Peer to Peer Lending dapat dibedakan menjadi dua macam, yaitu perlindungan secara preventif dan perlindungan hukum secara represif. Perlindungan hukum secara preventif adalah perlindungan hukum yang bertujuan untuk mencegah terjadinya sengketa. Dengan demikian perlindungan hukum ini dilakukan sebelum terjadinya sengketa. Perlindungan hukum bagi Pengguna Layanan Fintech berbasis Peer to Peer Lending sebelum terjadinya sengketa dapat dilakukan dengan upayaupaya dari Penyelenggara layanan Fintech.

20 Basrowi, "Analisis Aspek dan Upaya Perlindungan Konsumen Fintech Syariah,” Lex Librum Journal, Vol. V, No. 2, Juni 2019, . 969.

${ }_{21}$ Basrowi, "Analisis Aspek dan Upaya Perlindungan Konsumen Fintech Syariah," Lex Librum Journal, Vol. V, No. 2, Juni 2019,... 969. 
Upaya Penyelenggara sebelum terjadinya sengketa adalah dengan menerapkan prinsip dasar perlindungan hukum bagi Pengguna layanan Fintech. prinsip-prinsip tersebut diatur pada Pasal 29 POJK Nomor 77/POJK.01/2016 Tentang Layanan Pinjam Meminjam Uang Berbasis Teknologi Informasi antara lain prinsip transparansi, perlakuan yang adil, keandalan, kerahasiaan dan keamanan data, dan penyelesaian sengketa Pengguna secara sederhana, cepat dan biaya terjangkau.

b. Perlindungan Hukum Secara Represif

\begin{tabular}{cc}
\multicolumn{2}{c}{ Perlindungan hukum } \\
secara represif adalah
\end{tabular} perlindungan hukum yang tujuannya untuk menyelesaikan sengketa. Perlindungan hukum ini baru bisa dilakukan setelah timbulnya sengketa terlebih dahulu. Sengketa dalam Penyelenggaraan Fintech berbasis Peer to Peer Lending bisa terjadi antara Pengguna dengan Pengguna lainnya maupun dengan antara Pengguna dengan Penyelenggara. Jika sengketa tersebut benar terjadi maka ada mekanisme tertentu untuk dapat menyelesaikan masalah tersebut. Pihak yang merasa dirugikan dapat mengajukan pengaduan agar sengketa yang terjadi dapat segera terselesaikan Dengan adanya tindakan pengaduan dari Pengguna layanan Fintech berbasis Peer to Peer Lending kepada Penyelenggara platform Fintech, hal tersebut membuat Penyelenggara harus segera menindak lanjutinya.

Setelah menerima pengaduan dari pihak yang dirugikan dalam hal ini Pengguna Fintech, sebagaimana Pasal 38 POJK Nomor 1/POJK.07/2013 tentang Perlindungan Konsumen Sektor Jasa Keuangan bahwa pelaku jasa keuangan dalam hal ini adalah Penyelenggara layanan Fintech berbasis Peer to Peer Lending wajib melakukan: a) Pemeriksaan internal atas pengaduan secara kompeten, benar, dan obyektif; b) Melakukan analisis untuk memastikan kebenaran pengaduan; dan c) Menyampaikan pernyataan maaf dan menawarkan ganti rugi (redress/remedy) atau layanan, jika pengaduan konsumen benar. $^{22}$

POJK tersebut $\begin{array}{rr}\text { Berdasarkan apabila } \\ \text { Pentuan }\end{array}$ dikemudian hari terjadi tindakan gagal bayar oleh Penerima pinjaman dan gagal bayar tesebut terbukti akibat kesalahan atau kelalaian dari penyelenggara, maka Penyelenggara wajib memberikan ganti rugi atas perbuatannya tersebut.

Upaya yang dilakukan dalam peningkatan perlindungan konsumen Fintech di Wilayah III Cirebon adalah:

1) Pemblokiran

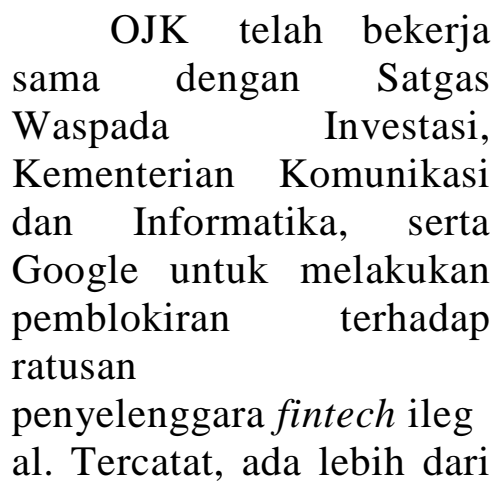

22 Basrowi, "Analisis Aspek dan Upaya Perlindungan Konsumen Fintech Syariah," Lex Librum Journal, Vol. V, No. 2, Juni 2019,... 971. 


400 laman dan
aplikasi fintech ilegal yang
telah diblokir hingga
sekarang. Pemblokiran ini
dilakukan tak lama setelah
OJK melakukan
inventarisasi
terhadap fintech ilegal
tersebut.
Kemudian
berkoordinasi dengan
Kemenkominfor untuk
memblokir situs dan
aplikasi penyelenggara
fintech ilegal apabila
mendapat permintaan dari
OJK. Pemblokiran ini
sebagai cara mendorong
dan memperkenalkan
bisnis fintech aman di
Indonesia. OJK juga
meningkatkan literasi
keuangan sekaligus
memberikan perlindungan
kepada masyarakat.

\section{2) Pencabutan Izin}

OJK memastikan mencabut tanda terdaftar dan status penyelenggara apabila fintech terbukti me lakukan penyalahgunaan data nasabah seperti mengakses data telepon dan file gambar. Selain itu, OJK juga tidak memberikan izin kepada fintech yang terbukti melakukan pelanggaran terhadap nasabah. OJK pernah membatalkan lima penyelenggara fintech kare na dianggap tidak mampu meneruskan kegiatan operasional disertai rencana penyelesaian hak dan kewajiban pengguna. Kelima penyelenggara fintech terse but, yakni Relasi, Tunaiku, Dynamic Credit, Pinjamwinwin, dan Karapoto.

Dengan pembatalan tanda terdaftar tersebut maka para penyelenggara fintech terse but harus menghentikan seluruh kegiatan layanan pinajm-meminjam uang berbasis teknologi informasi, menyelesaikan hak dan kewajiban pengguna, dan dilarang mencantumkan logo OJK serta pernyataan terdaftar dan diawasi oleh OJK dalam setiap kegiatan.

\section{E. Penutup}

Berdasarkan uraian pembahasan tentang tersebut dapat disimpulkan bahwa:

1. Dasar hukum melawan permainan Fintech abal-abal adalah Peraturan Bank Indonesia No.19/12/PBI/2017 tentang Penyelenggaraan Teknologi Finansial (PBI Tekfin), Peraturan Otoritas Jasa Keuangan No.77/POJK.01/2016 tentang Layanan Pinjam Meminjam Uang Berbasis Teknologi Informasi, dan dengan Peraturan OJK No. 13/POJK.02/2018 tentang Inovasi Keuangan Digital di Sektor Jasa Keuangan. Aturan ini merupakan ketentuan yang memayungi pengawasan dan pengaturan industri financial technology (Fintech).

2. Upaya Peningkatan Perlindungan Konsumen Fintech di Wilayah Cirebon adalah OJK melakukan pengembangan regulasi guna melindungi nasabah fintech. Pengembangan regulasi juga dilakukan guna memperkuat Peraturan Otoritas Jasa Keuangan (POJK) Nomor 77/POJK.01/2016 tentang Layanan Pinjam Meminjam Uang Berbasis Teknologi Informasi. Salah 
satu pengembangan regulasi yang dilakukan OJK adalah dengan mengeluarkan peraturan OJK Nomor 13/POJK 02/2018 mengenai inovasi keuangan digital di sektor keuangan.

\section{DAFTAR PUSTAKA}

Basrowi, Analisis Aspek dan Upaya Perlindungan Konsumen Fintech Syariah, Lex Librum Journal, Vol. V, No. 2, Juni 2019.

Dimyati Khudzaifah dan Kelik Wardiono, Metode Penelitian Hukum (Buku Pegangan Kuliah), Surakarta: Universitas Muhammadiyah Surakarta, 2015.

Ernama, Budiharto, Hendro S., Pengawasan Otoritas Jasa Keuangan Terhadap Financial Technology (Peraturan Otoritas Jasa Keuangan Nomor 77/POJK.01/2016), Diponegoro Law Journal, Vol. 6, No.3, (2017).

H. Salim HS dan Erlies Septiana Nurbani, Penerapan Teori Hukum Pada Penelitian Tesis dan Disertasi, Jakarta: PT RajaGrafindo Persada, 2013

Mertokusumo Sudikno, Mengenal Hukum Suatu Pengantar, Yogyakarta: Universitas Atma Jaya Yogyakarta, 2010.

Pane Erina, Perlindungan Konsumen dalam Persperktif Undang-Undangan Perlindungan Konsumen dan Hukum Islam, Prananta Hukum Vol. 2 No. 1, Januari 2007.

Raharjo Sajipto, Ilmu Hukum, Bandung: PT Citra Aditya Bakti, 2014, cet. Ke-8.

Soekanto Soerjono, Pengantar Penelitian Hukum, Jakarta: Penerbit Universitas Indonesia (UI-Press), 2005.

Soerjono Soekanto dan Sri Mamudji, Penelitian Hukum Normatif Suatu Tinjauan Singkat, Jakarta; Rajawali Press, 2010.

Ratusan Warga Cirebon Terjebak Rentenir Online,

https://www.radarcirebon.com/2019/0 7/25/ratusan-warga-cirebon-terjebak- rentenir-online/ diakses pada tanggal 18 Agustus 2019.

Rani Maulida, Fintech: Pengertian, Jenis, Hingga Regulasinya di Indonesia, https://www.online-

pajak.com/tentang-pajak-

pribadi/fintech diakses pada tanggal 27 November 2019.

Sylke Febrina Laucereno, Basmi Rentenir Online, Undang-undang Fintech Harus Dibuat!, https://finance.detik.com/fintech/d4649564/basmi-rentenir-onlineundang-undang-fintech-harus-dibuat, Jumat, 02 Agustus 2019, diakses pada tanggal 18 Agustus 2019 pukul 20.06 WIB.

detikFinance.com, Selasa 10 Januari 2017 17:31 WIB, OJK Keluarkan Aturan Fintech, dalam http://www.detikfinance.com, diakses Kamis, 8 Maret 2019 pukul 15:10 WIB.

Sejak 2017, OJK Sudah Temukan 2.500 Fintech Tak Berizin, 29 Mei 2020. https://www.radarcirebon.com/2020/0 5/29/sejak-2017-ojk-sudah-temukan2-500-fintech-tak-berizin/ diakses pada tanggal 01 Juni 2020.

Abi Tisnadisastra dalam seminar Himpunan Konsultan Hukum Pasar Modal (HKHPM), Rabu, 28 Februari 2018, Aspek Hukum Fintech di Indonesia yang Wajib Diketahui Lawyer, https://www.hukumonline.com/berita/ baca/1t5a97b394460ec/aspek-hukumfintech-di-indonesia-yang-wajibdiketahui-lawyer/ diakses pada tanggal 29 Mei 2020.

Herdaru Purnomo, Indonesia Kini Punya Payung Hukum Aturan Fintech, 01 September 2018, https://www.cnbcindonesia.com/tech/2 0180901144740-37-31329/indonesiakini-punya-payung-hukum-aturanfintech diakses pada tanggal 20 Juni 2020. 
Peraturan Bank Indonesia No.19/12/PBI/2017 tentang Penyelenggaraan Teknologi Finansial.

Peraturan Bank Indonesia No.11/12/PBI/2009 jo. PBI No.16/8/PBI/2014 jo. PBI No. 18/ 17 /PBI/2016 tentang Uang Elektronik (Electronic Money).

Peraturan Bank Indonesia No.18/40/PBI/2016 tentang Penyelenggaraan Pemrosesan Transaksi Pembayaran.

Peraturan Bank Indonesia No.18/40/PBI/2016 tentang Penyelenggaraan Pemrosesan Transaksi Pembayaran.

Peraturan Otoritas Jasa Keuangan Nomor 1/POJK.07/2013 tentang Perlindungan Konsumen Sektor Jasa Keuangan.

Peraturan Otoritas Jasa Keuangan No.77/POJK.01/2016 tentang Layanan Pinjam Meminjam Uang Berbasis Teknologi Informasi.

Peraturan Otoritas Jasa Keuangan No. 39/POJK.04/2014 tentang Agen Penjual Efek Reksadana

Peraturan Otoritas Jasa Keuangan No. 69/POJK.05/2016 tentang Penyelenggaraan Usaha Perusahaan Asuransi.

Peraturan Otoritas Jasa Keuangan No. 13/POJK.02/2018 tentang Inovasi Keuangan Digital di Sektor Jasa Keuangan.

Surat Edaran Otoritas Jasa Keuangan Nomor 18/ SEOJK.02/2017. 